\title{
A Three-Layers Theoretical Framework For Analyzing Public Private Partnerships: The Italian Case
}

Nunzia Carbonara

DMMM, Politecnico di Bari,

Viale Japigia 182, Bari, Italy

ncarbonara@poliba.it
Nicola Costantino

DMMM, Politecnico di Bari,

Viale Japigia 182, Bari, Italy

costantino@poliba.it
Roberta Pellegrino

DMMM, Politecnico di Bari,

Viale Japigia 182, Bari, Italy

r.pellegrino@poliba.it
DOI 10.5592/otmcj.2013.3.5

Research paper

\section{Keywords}

PPPs, Country,

Sector, Project
THE APPLICATIONS OF PPP ALL OVER THE WORLD VARY FROM COUNTRY TO COUNTRY. International literature lacks of contributions focusing on cross-country and cross-sector description, analysis and comparison of Public Private Partnerships (PPPs). The present paper aims at developing a framework for characterizing PPPs in various countries. The theoretical framework is divided in three layers: country, sector and project layers. Each layer is characterized by a set of dimensions and each dimension is characterized by a set of variables that are highly relevant to characterize PPPs. The proposed framework has been applied to characterize PPPs implementation in Italy, with a particular focus on the transport sector. 


\section{INTRODUCTION}

In the 2oth century, the more and more widespread adoption of Project Financing (PF) was encouraged by the need for getting financial resources to carry out infrastructure projects without recourse, that is, by offering to the lenders only guarantees about the expected revenues of the project. Public Private Partnerships (PPPs), known as “agreements where public sector bodies enter into longterm contractual agreements with private sector entities for the construction or management of public sector infrastructure facilities by the private sector entity or the provision of services [...] by the private sector entities on behalf of a public sector entity" (Grimsey and Lewis, 2002), became popular because of the possibility to use the instruments offered by PF for the construction of facilities. More specifically, PPPs are collaborations between public governments and private firms aiming at providing services and infrastructures traditionally delivered by public sector.

The earliest adopter of a specific legislation for PPP among European countries was the United Kingdom, where Private Financing Initiative (PFI) was officially introduced in 1992 (Spackman, 2002). Nowadays, PPPs are ruled by specific laws in many EU and not EU countries (Bovis, 2010; Clifton and Duffield, 2006; US Department of Transportation, 2007) and the use of such an instrument to provide public services and infrastructure is more and more widespread. However, the principles of the term PPP are understood in many different ways nationally and even within the various sectors. The implementation of PPP has its own features which are often very different across countries and sectors (Hemming, 2006; Turina and Car-Pusic, 2006). While several studies analyze the characteristics of PPP in some specific countries, such as Akintoye (2009), Smith (2009), Li and Akintoye (2003), the international literature lacks of contributions aiming at developing a common framework to analyze and compare PPP across sectors and countries. In order to fill this gap the purpose of this paper is to review literature on PPP with the aim at defining a set of parameters/criteria characterizing the whole spectrum of PPP. Based on these parameters/criteria, a three-layer framework for characterization of PPP was developed. At the first layer we pose the country in which the PPP is adopted, at the second layer we pose the sector, and finally the third layer of analysis focuses on the project structure of PPP. Each layer is characterized by a set of dimensions and each dimension is characterized by a set of variables that are highly relevant to characterize PPP. The proposed framework was applied to characterize PPP implementation in Italy. Focusing on the four modes of the transport sector, we test if and how all the dimensions and variables work sufficiently in a cross-sectorial context, thus posing the base for further comparisons of PPP application in different countries.

The remainder of the paper is structured as follows. A brief literature review and the research motivation are presented in Section 2. The PPP analysis framework is proposed in Section 3 , while Section 4 applies the framework to the Italian case. Finally, Section 5 concludes the paper.

\section{Research background}

An extensive literature has contributed to the debate and the understanding of PPP in a number of ways. This covers multiple disciplines, including public administration (Koppenjan, 2005), public management (Ysa, 2007), construction and project management (Koch and Buser, 2006), legal studies (Tvarnø, 2006) and project finance (Grimsey and Lewis, 2002), just to mention a few.

Researchers have investigated different aspects of PPPs: PPP risks; PPP finance; the concession selection, the critical success factors and/or barriers for PPP projects, etc. (Garvin and Ford, 2012; Li et al., 2005a; Li et al., 2005b; Jefferies et al., 2002; Schaufelberger and Wipadapisutand, 2003; Zhang, 2005a; 2005b).

However, the analysis of the application, diffusion, and success of PPPs all over the world points out that the PPP projects implementation varies from country to country, from sector to sector, and from project to project (Hemming, 2006; Turina and Car-Pusic, 2006). For these reasons, studies aimed at characterizing PPPs address this issue focusing on a specific country and/or a specific sector or on specific cases of PPP projects.

In particular, studies operating with single country research designs have typically dealt with policy and regulation issues of PPPs (Spackman, 2002; Reeves, 2003; Deakin, 2002; Klijn and Teisman, 2003; Flinders, 2005; Koppenjan, 2005; Johnston and Gudergan, 2007), whereas comparative approaches are generally rare in this field of research (although for a few notable exceptions; see Greve and Hodge, 2007; McQuaid and Scherrer, 2010).

Recognizing that the differentiation in PPP implementation can be traced back to the Government's Role and its capability to manage projects, studies in the field of new public management have investigated the presence of an adequate legal/regulatory frameworks at a country level (Abdel Aziz, 2007; Koch and Buser, 2006; Pongsiri, 2002).

Because of the characteristics of industry sectors are not uniform, researchers have recognized that each sector offers unique challenges and opportunities for PPPs due to differing legal, regulatory and investment considerations. Accordingly, PPP performance and its characteristics vary by sector to sector. Harris (2003) studies the trend of private sector investments in infrastructure by sector, highlighting 
the different capability of each sector to attract private participation. ESCAP (2011) points out that physical, natural, and technological characteristics of sectors influence the implementation of PPPs in the planning and design of the project. Roumboutsos et al. (2013), analysing 24 cases originating from 13 countries in Europe, find that the PPP implementation and its successes vary by sector.

A greater number of researchers studies PPP by adopting a case study research approach (Akintoye, 2009; Hodge and Greve, 2005). The review of these cases shows that the diversity of PPP projects is due to the large and complex activities "bundled" into the contractual arrangements, the number of parties and their involvement level in the transaction, and other project-related features (Roumbout sos et al., 2013).

Although there is a wide literature on the analysis of PPP, studies adopt a mono-dimensional perspective, namely a country, sector, and projectspecific standpoint, thus not providing a comprehensive understanding of PPP. This study contributes to fill this gap by developing a framework that allows a comprehensive analysis of PPP.

\section{The proposed PPP analysis framework}

Recognizing that the PPP implementation is affected by the country context where the project is developed, the structure of the sector, and is projectspecific, the proposed framework devoted to a comprehensive analysis of PPP is structured on three layers. At the first layer we pose the country in which the PPP is adopted, at the second layer we pose the sector, and finally the third layer of analysis focuses on the project structure of PPP. Each layer is characterized by a set of dimensions and each dimension is characterized by a set of variables that were identified and defined by reviewing the literature on PPP.
According to the literature, at the country-layer we associated four main dimensions: institutional, legal, economic, and financial (Dewulf et al., 2012). The first two dimensions refer to the presence of a specific institutional mindset supporting the development of PPP and a legal/statutory framework at a national level (Hammerschmid and Ysa, 2010). These could promote the PPP and facilitate the delivery of complex projects by centralizing and streamlining planning approval, or coordinating actions with the private sector in implementing PPP. With this regard, Hammerschmid and Ysa (2010) identify three main aspects that can be expected to have a considerable effect on the diffusion and implementation of PPPs in a country, namely the establishment of a PPP task-forces, PPP legislation, and specific government initiatives to foster PPPs. The other two variables characterize the economic (Qiao et al., 2001; Zhang, 2005c) and financial conditions ( $\mathrm{Li}$ et al., 2005) of the country. They can be useful to understand the country propensity to use PPP method to deliver public infrastructure.

For the sector-layer the literature suggests the following dimensions: Industry organization, market structure, and performance. The industry organization is characterized by two variables: the regulatory regime expressing the level of regulation of the specific sector (Devapriya, 2006), and the organizational structure explaining the level of private sector participation that characterizes the specific sector (Estache and Serebrisky, 2006). Market structure can be characterized in terms of two variables: the level of demand of the sector and the level of supply. The latter depends on the number of competitors. Finally, the last dimension that characterizes the sector level is the performance that can be evaluated by using attractiveness and/or profitability indexes characterizing the sector.
PPP projects are described in the literature by a set of variables that can be grouped in two categories: the structure of PPP arrangements and financing of PPP arrangements (Carbonara et al., 2012). These represent the two dimensions of the project-layer, which characterize PPP arrangements between public and private parties and can be considered endogenous to the transaction. This justifies why, even if there could be a best practice on each of these dimensions, they often assume different values due to the specificity of the PPP transaction. As far as the structure of PPP/PFI is concerned, the first variable that characterizes this dimension is the PPP model or contract type. In general, PPP comes in a wide variety of models such that there is often no clear agreement on what does and what does not constitute a PPP form (Hemming, 2006). The definition of PPP depends also on the country concerned (Turina and Car-Pusic, 2006), and this in part demonstrates the continued lack of standardization of nomenclature with respect to PPP structures (European Commission, 2004). PPP arrangements range from management contract (with little or no capital investment) through concession contracts (which may encompass the design and build of assets along with the provision of a range of services and the financing of the entire construction and operation), to joint ventures characterized by the sharing of ownership (and sometime also management) between the public and private sectors (Costantino et al., 2009). Based on the legal structure that characterizes the transaction, two main categories can be identified: institutional PPP and contractual PPP (European Commission, 2004). The first involves the establishment of an institutional legal entity held jointly by the private and public partners in order to supply an infrastructure or service to the community. The second only involves a contractual link between the private and 
public parties (Bovis, 2010). It assumes that the private party will partially or totally finance the project, in exchange of some form of compensation from final users or through regular payments by the public authority (revenues/payments). The payments from the public sector are generally based on usage volumes or demand (i.e., payments in lieu of fees or tolls for public lighting, hospitals, schools, roads with shadow tolls). Sometimes, however, they are given as lump sum payment, i.e., a form of financial contribution to assure the economic and financial feasibility of the project. From an economic and managerial point of view, the institutional PPP do not differ so much from the contractual ones. Another classification of PPP models is based on operational aspects of the transaction, according to the remit of the private sector. The PPP model usually requires the use of private expertise and management skills, which should be one of the main reasons of a PPP implementation. This variable refers to the complexity and importance of the operational phase (in front of the design and construction phases) in the contract. The development of PPP project usually requires the private sector to be involved in almost all the phases of a project lifecycle. The public sector, in fact, should develop these alliances with the aim of exploiting the private sector's resources and expertise in the provision and delivery of public service and, accordingly, improving the efficiency and quality of services. The PPP relations generally last long (contract duration), for typically 25-30 years (Chinyio and Gameson, 2009). An adequate length of time is often required to ensure investment and profit recovery (European Commission, 2004). When the contract is signed, a new company is generally created which is called 'special purpose vehicle' (SPV). It is an independent legal entity that would generally include a construction company, a facility management firm and a financial institution (Chinyio and Gameson, 2009). The structure, however, depends on the characteristics of the specific PPP project/transaction. The SPV could be a company completely private or jointly held by the private and public sectors. Risk allocation is another very important aspect of PPP transactions, maybe the most important one. As Bing et al. (2005) state, at the beginning of the use of PPP/PFI, governments appeared to view PPP projects primarily as a way of getting infrastructure costs off the public balance sheet, keeping investment levels up, cutting public spending and avoiding the constraints of public sector borrowing limits. Afterwards, the increasing use of PPP has led governments to see it a new approach to risk allocation in public infrastructure projects (Bing et al., 2005). The principle of risk allocation is to transfer the risks to the party that is best able to manage them. The aim, therefore, is (or should be) to optimise, not maximise risk transfer (Costantino et al., 2009). The second dimension selected to characterize the project layer was the financing of PPP/PFI arrangements. Fundamentally, in fact, the aim of PPP/PFI is to bring the private sector's finance as well as management skills into the provision of facilities and services traditionally delivered by public sector (Katz and Smith, 2003). Usually PPP projects are financed by the private party on a "nonor limited recourse basis" (Ye, 2009). This way, the private sector involvement allows projects to obtain more favorable long-term financing options and obtain this financing in a much quicker timeframe (NCPPP, 2003). At the same time, the possibility to privately finance public infrastructure and projects traditionally funded by public finance allows governments to cope with the ever-increasing demands on their budgets. The private financing can be total or partial. In this last case, there is even a financial contribution from the public sector. Three general funding options are used in financing a project: equity, subordinate debt (also called mezzanine financing or quasiequity) and senior debt (Ye, 2009; Chinyio and Gameson, 2009). Each kind of fund is exposed to different level of risks and therefore requires different returns. Consequently, the capital structure falls into ranges from total equity to total debt financing. In general, PPP projects are financed using a combination of both with varying ratios of equity to debt. Usually, debt financing exceeds $70 \%$ (Ye, 2009): the debt to equity gearing is often 90:10, but can start from 95:5 (Chinyio and Gameson, 2009). The complexity of a PPP arrangement and the consequent high transaction costs involved in setting up a PPP/PFI transaction require an adequate dimension of the initiative, i.e., a high investment value (Chinyio and Gameson, 2009). Table 1 shows the three-layers PPP framework.

\section{Application of the proposed framework}

The proposed framework has been applied to characterize PPPs implementation in Italy, with a particular focus on the transport sector. To do this, we have reviewed the theoretical and empirical studies available in the literature and collected data and information on Italian PPPs. These have been used to assign the values to variables of the framework.

The implementation of PPP in Italy is a very recent practice. In fact, even though in 1994 and 1998 the Merloni law set the framework for using private sector contractors, only later a special PPP taskforce (Unità Tecnica Finanza di Progetto, UTFP - Technical Unit for Project Finance), was created and its powers were reinforced in 2001. The first example of Italian PPP can be considered TAV (Treni ad Alta Velocità), a both publicly and privately owned company created in order to carry out a high-speed railway network in Italy 


\begin{tabular}{|c|c|c|c|c|}
\hline Layers & Dimensions & \multicolumn{2}{|l|}{ Variables } & Values \\
\hline \multirow{10}{*}{ 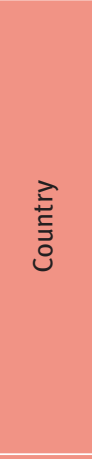 } & \multirow{4}{*}{ Institutional } & \multicolumn{2}{|l|}{ Political-ideological influences } & Existence of national programs supporting PPP \\
\hline & & \multirow{2}{*}{\multicolumn{2}{|c|}{ Design of government institutions }} & Centralist \\
\hline & & & & Federalist \\
\hline & & \multicolumn{2}{|c|}{$\begin{array}{l}\text { Attitude towards and use of New Public Management in } \\
\text { public administration }\end{array}$} & Degree of outsourcing of public services to private sector \\
\hline & Legal & \multicolumn{2}{|c|}{$\begin{array}{l}\text { PPP formalization by a Government legal/statutory } \\
\text { framework }\end{array}$} & $\begin{array}{l}\text { Degree of level of regulation by the legal framework (all/few } \\
\text { aspects of PPP are formally regulated through the framework) }\end{array}$ \\
\hline & \multirow{4}{*}{ Economic } & \multicolumn{2}{|l|}{ Taxation and its change } & Level of taxation \\
\hline & & \multicolumn{2}{|l|}{ Indebtedness } & Level of public debt \\
\hline & & \multirow{2}{*}{\multicolumn{2}{|c|}{ Investment needs }} & Development of new infrastructure \\
\hline & & & & Maintenance of existing infrastructure \\
\hline & Financial & Access to capital and credit & & Existence of strong constraints to obtain capital/credit \\
\hline \multirow{9}{*}{ 六 } & \multirow{3}{*}{$\begin{array}{l}\text { Industry } \\
\text { organization }\end{array}$} & \multirow{2}{*}{\multicolumn{2}{|c|}{ Regulatory regime }} & Regulated \\
\hline & & & & Deregulated \\
\hline & & \multicolumn{2}{|l|}{ Organizational structure } & Level of private sector participation \\
\hline & \multirow{5}{*}{ Market Structure } & \multirow{2}{*}{\multicolumn{2}{|c|}{ Demand }} & Level of demand \\
\hline & & & & Elasticity of demand \\
\hline & & \multirow{3}{*}{\multicolumn{2}{|c|}{ Competitors }} & Market monopoly \\
\hline & & & & Existence of substitute services (in other subsectors) \\
\hline & & & & Existence of substitute routes (in the same subsector) \\
\hline & Performance & Attractiveness/profitability & & Potential revenues/earnings \\
\hline & \multirow{23}{*}{$\begin{array}{l}\text { PPP } \\
\text { arrangement's } \\
\text { structure }\end{array}$} & & Based on the legal & Institutional PPP \\
\hline & & & $\begin{array}{l}\text { structure of the } \\
\text { transaction }\end{array}$ & Contractual PPP \\
\hline & & & & Management contract \\
\hline & & & & Leasing model or Build-Lease-Transfer \\
\hline & & Contract type & & Design-Build (and Design-Build with warranty) \\
\hline & & & Based on operational & Design-Build-Operate-Maintain \\
\hline & & & aspects & Design-Build-Finance-Operate \\
\hline & & & & Build-Operate-Transfer \\
\hline & & & & Build-Own-Operate-Transfer \\
\hline & & & & Build-Own-Operate \\
\hline & & Use of private resources and & tise & $\begin{array}{l}\text { Degree of involvement of the private sector in the lifecycle } \\
\text { of the project (from design to management) }\end{array}$ \\
\hline & & Time horizon of contract & & Medium term (less than 25 years) \\
\hline & & 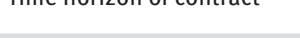 & & Long term (more than 25 years) \\
\hline & & & Payments based on & By private sector \\
\hline & & & usage volumes or & By public sector \\
\hline & & Revenues sources & demand & By public and private sectors \\
\hline 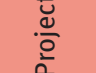 & & & $\begin{array}{l}\text { Public financial } \\
\text { contribution }\end{array}$ & Lump sum payment by public sector \\
\hline & & & Comnany ownershin & Private company \\
\hline & & special purpose & compainy ovvitetsmip & Publicly- and privately-held company \\
\hline & & & Partnership structure & Number and composition of partners \\
\hline & & & & Private sector \\
\hline & & Risk allocation & & Public sector \\
\hline & & & & Shared between public and private sectors \\
\hline & & & & Financing in whole by the private sector \\
\hline & & Use of private finance & & Financing partially by the private sector \\
\hline & & & & Government-funded projects (no private capital) \\
\hline & & & & Bank debt \\
\hline & & & & Equity \\
\hline & arrangement's & Type of funding options & & Bonds \\
\hline & & & & Loan from shareholders \\
\hline & & & & Mezzanine finance \\
\hline & & Debt to equity gearing & & Low (debt below 70\%) \\
\hline & & Ded to equiry searmis & & High (debt exceeds 70\%) \\
\hline & & Investment value & & Low \\
\hline & & mestinetil vatue & & High \\
\hline
\end{tabular}

Table 1. The three-layers PPP framework: dimensions and variables. 


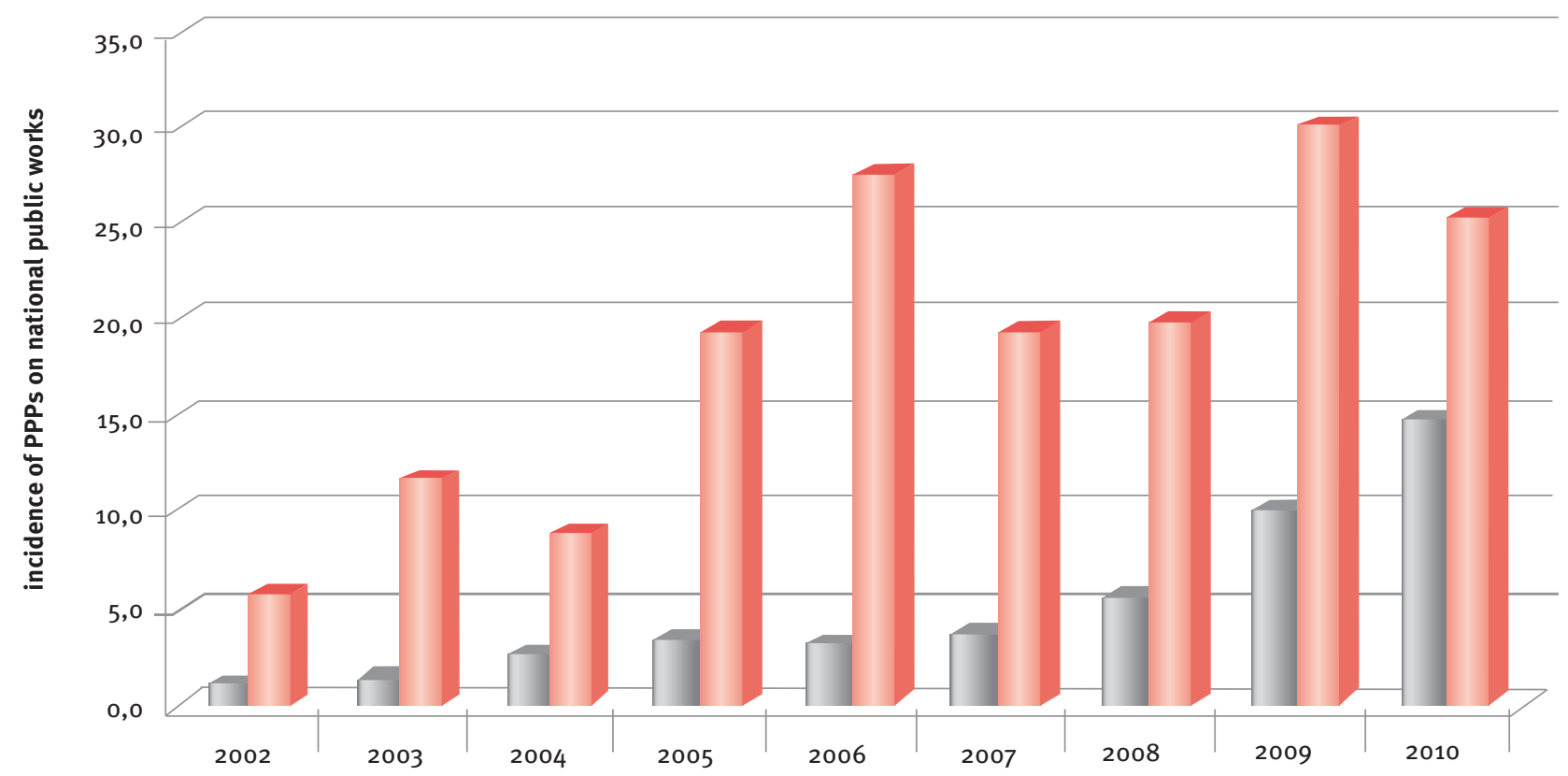

number of bids

total capital value $(\mathrm{ml} €)$

Figure 1. Incidence of PPP Italian projects on the total amount of bids for national public works

(Presilla, 2006). This initiative was encouraged by new apposite laws regarding railway services. The following creation of a complete legislative framework, given by the Merloni law in 1994 and, successively, by the Code of Works, Services and Supplies Public Contracts in 2003 (Vigliano and Bicchieri, 2007), favored the first adoptions of this instrument by both central and local governments and public companies (particularly, ANAS, managing national roads, and $\mathrm{RFI}$, managing national railroads) (OECD, 2010). Most of the Italian PPP contracts have been mainly used in power sectors by involving the private sector on a concessionstyle basis. Other projects have been in roads, light railway and health services. In Figure 1 shows the incidence of PPP projects on the total amount of bids for national public works during the period 2002-2010.

The Figure shows a significant positive trend in the adoption of PPP as a way of delivering public services and infrastructures. There are a lot of reasons that make the application and use of PPP less effective and efficient in Italy than in other countries. In particular, with regard to the administrative issues, three main factors contribute to slow down the use of PPP: 1) the complexity of the administrative procedures and the distortions of competition due to the so-called "right of pre-emption" ${ }^{1}$, which was used to discouraged firms to participate to biddings; 2) the difficulty of regulating through contracts a proper allocation of risks, due to the "civil law" system in force in Italy; 3) the high administrative risk characterizing the

\footnotetext{
In the award of a public infrastructure contracts through project finance, if the best bid is the one of the project promoter, the contract is immediately awarded to it. If the best bid is the one of other competitors, the pre-emption right gives the promoter the possibility to adapt its bid to the best one, and award the contract.

The pre-emption right introduced in 2002 was removed in 2007 as a result of the pressures of the European Community that accused Italy of violating the Community principles of transparency and fair competition.
}

adjudication procedures (lossa and Antellini Russo, 2008).

With regard to the financial aspects, the main critical issue is the source of funding used for Italian PPP projects. The funding of PPP projects in Italy is generally granted by banks and rarely provided by capital market, by selling bonds or shares to investors (Etro, 2007). Using such a kind of funding gives disadvantages in comparison with other countries: the interest rate is about $10-11 \%$, while in UK, for instance, the required spread on the risk-free rate is about $0,75-1 \%$ (lossa and Antellini Russo, 2008). In addition to this, Italian banks tend to ask for traditional guarantees for the financing (Bentivogli et al., 2008) and this situation has been exacerbated by the recent financial crisis: nowadays, banks require greater spreads, reduced leverage and more guarantees in order to grant a loan. In addition to this, the mean duration of the loan was reduced (UTFP, 2010). As for the Italian Government's influence on the use of 


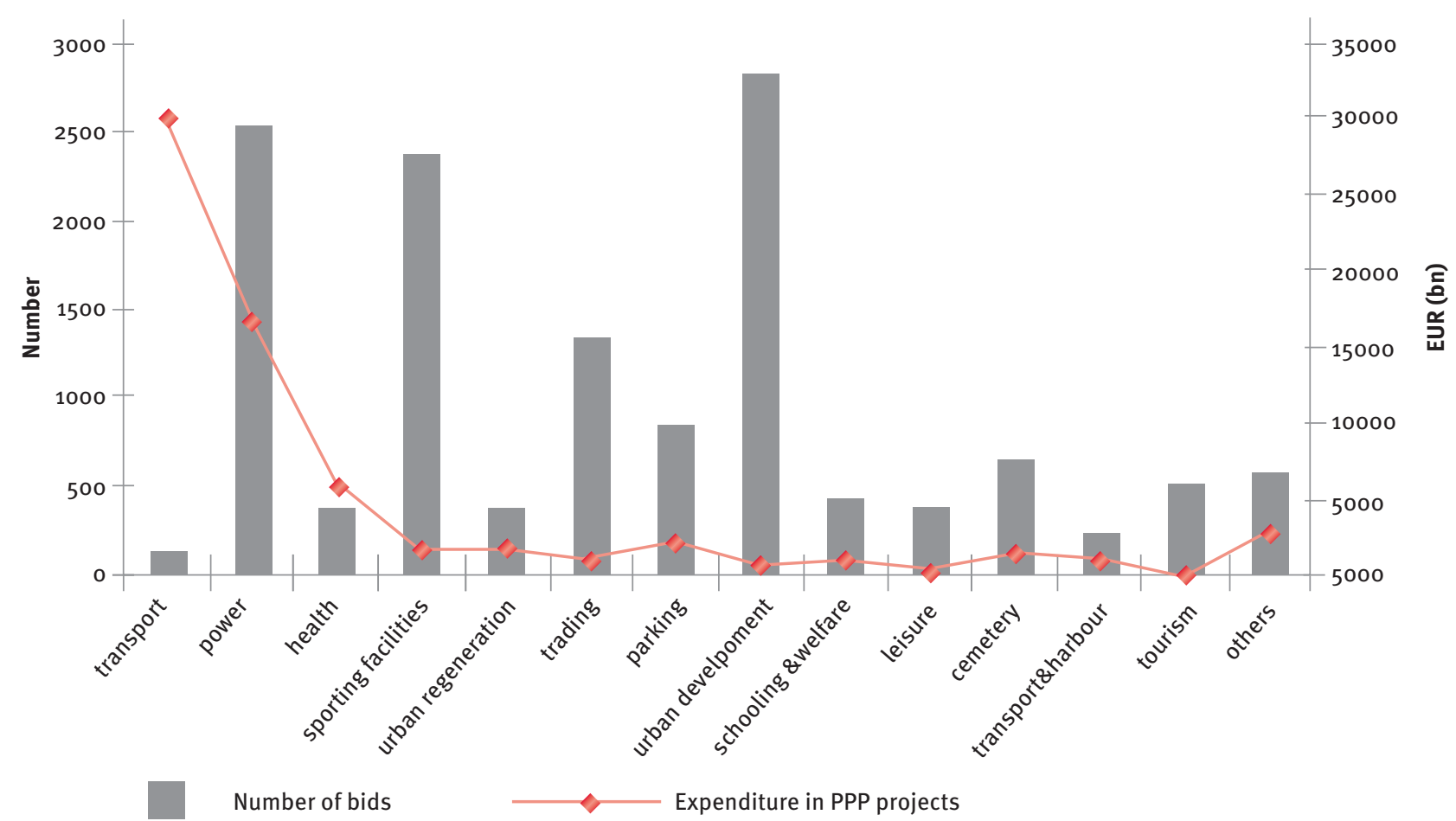

Figure 2. Number of bids and expenditure for PPP Italian projects by sector (2002-2011)

PPP there are still some shortcomings in the legislative regulation that does not allow the PPP to be used in an effective way. First of all, Italian law does not prescribe the estimation of Value for Money before the approval of a PPP project. Nowadays, the evaluation of the feasibility of a PPP project is simply based on the "Economic-Financial Plan" which is made by the private sponsor. Secondly, in Italy the SPV is normally formed by local or national Governments and/or public companies (Bentivogli et al., 2008), as a consequence the level of commitment of the private sector is quite minimized.

Finally, Figure 2 shows that an extensive use of PPP contracts is made for power projects, characterized by 2.527 bids and a total capital value of almost $€_{16} 671 \mathrm{bn}$. Other sectors with a relevant amount of PPP projects include sporting facilities, hospitals, urban developments, and other regional activities. Even if the number of transportation PPP projects has little relevance on the total, a significant expenditure characterizes these, with $€ 29.957$ bn mainly devoted to road networks. Consequently, the transportation sector becomes the most relevant in terms of expenditure.

Tables 2, 3 and 4 show the characterization of the Italian PPP according to the framework.

\section{Conclusions and Future Research} The applications of PPP all over the world vary from country to country, from sector to sector and from project to project. Such a differentiation has to be considered when the features of PPP and its implementation all over the world are studied. At the same time, research on PPP generally adopts a mono-dimensional perspective, namely a country, sector, and projectspecific standpoint, thus not providing a comprehensive understanding of PPP.

The present study has developed a framework that allows a characterization of PPP that involves all these three perspectives. The proposed framework was applied to characterize PPP implementation in Italy. Focusing on the four modes of the transport sector, we test if and how all the dimensions and variables work sufficiently in a cross-sectorial context.

Future research will be conducted on two directions.

A first research will be devoted to adopt the framework for a crosscountry analysis of PPP. Comparing PPP application in different countries, the framework represents a useful tool for deriving guidelines to support the implementation of PPPs that take into account the different contexts in which projects are implemented.

A second research will be devoted to develop a benchmarking tool based on the framework.

Assigning to each variable of the framework the appropriate value on the basis of theoretical studies and the analysis of real cases of successful PPP projects, this tool can be used by sponsors in order to derive managerial guidelines on how PPP projects should be correctly arranged and thus to move towards the best practices in applying PPP. 


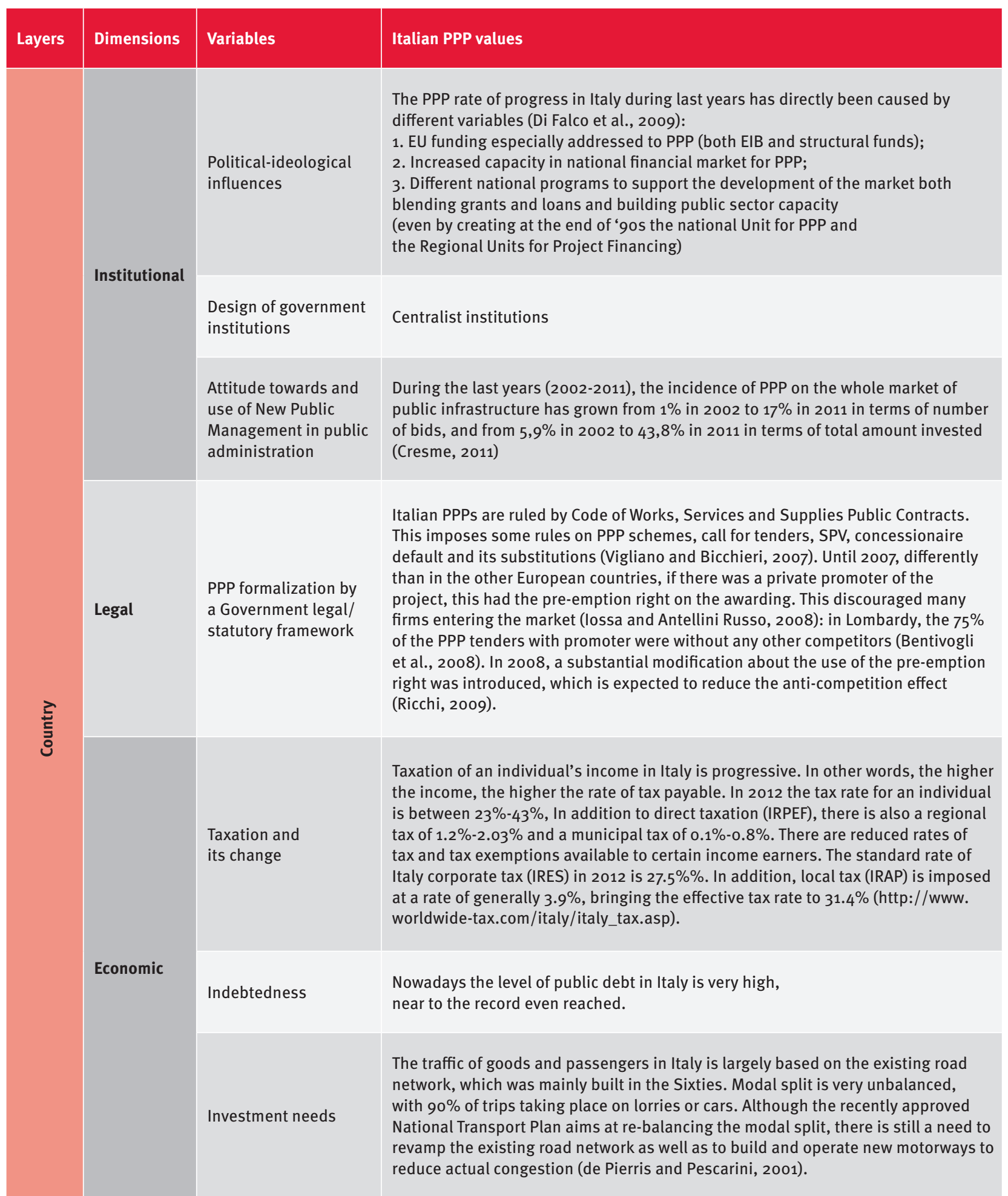

Access to capital and credit markets

The financial crisis has made more complex the access to capital and credit markets, for the following aspects (UTFP, 2009):

1. the difficulty in receiving funding and the substantial increase of the bank spread;

2. the reduction in the duration of funding;

3. the requirements of strong guarantees by bank and the increase

of the ratio equity to debt if compared to the past threshold.

Table 2. The application of the three-layers PPP framework for the Italian PPP: the country layer 


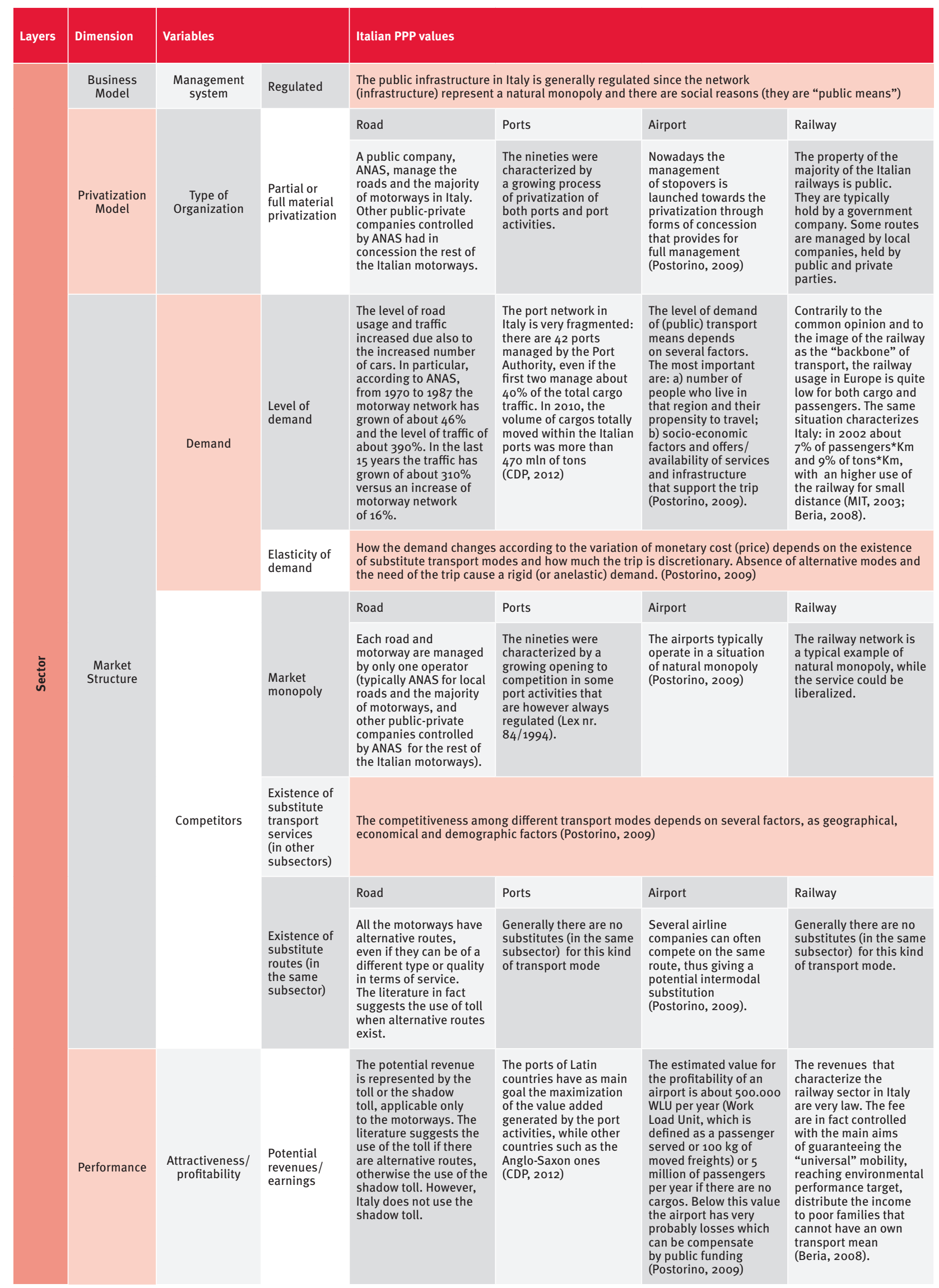

Table 3. The application of the three-layers PPP framework for the Italian PPP: the sector layer 


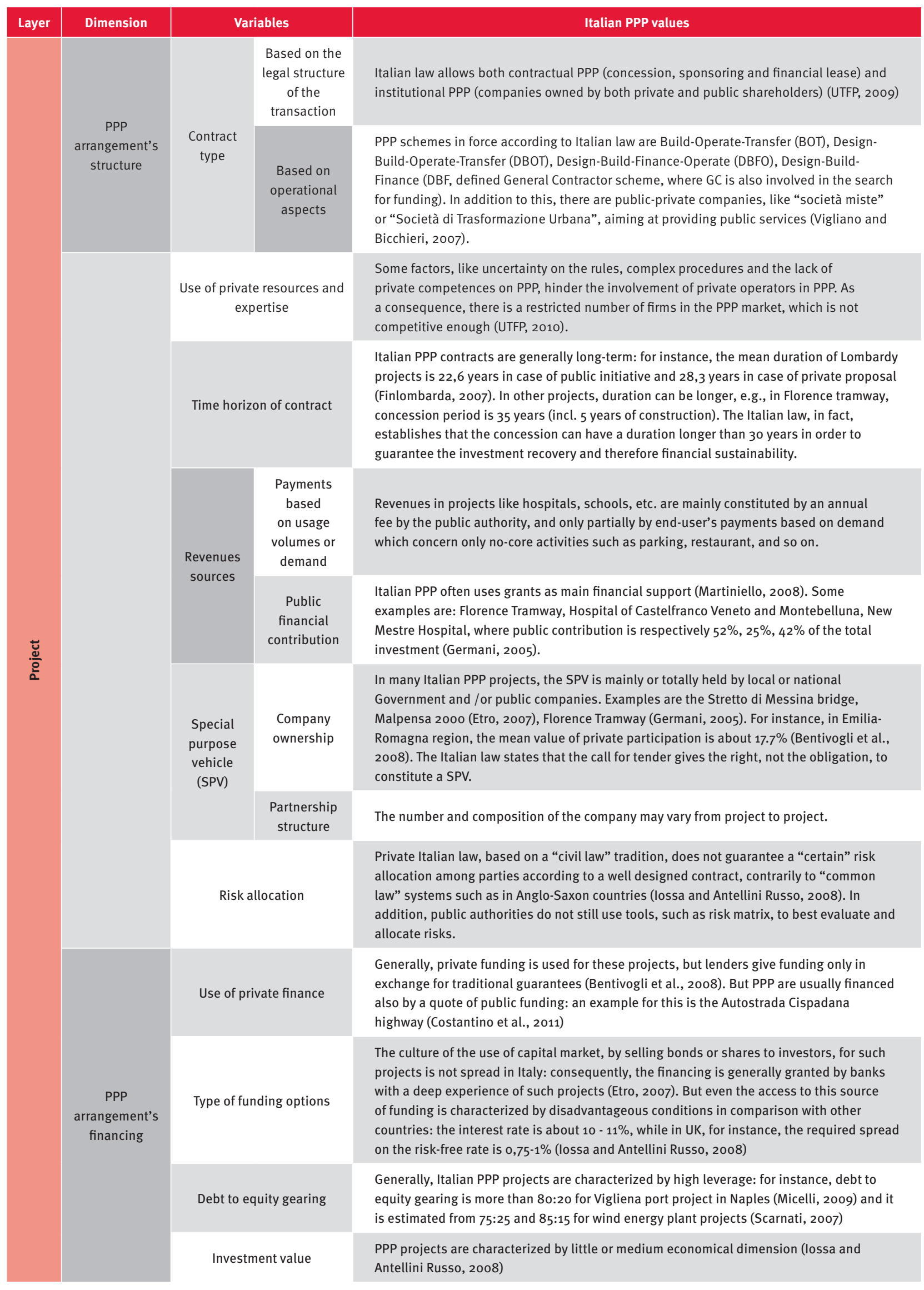

Table 4. The application of the three-layers PPP framework for the Italian PPP: the project layer 


\section{References}

Abdel Aziz, A.M. (2007). "Successful Delivery of Public-Private Partnerships for Infrastructure Development", Journal of Construction Engineering and Management, Vol. 133, No.12, pp. 918-931.

Akintoye, A. (2009). "PPPs for Physical Infrastructure in Developing Countries". In Akintoye, A. \& M. Beck (Eds.). Policy, Finance \& Management for Public-Private Partnerships (pp. 123-141). Wiley-Blackwell.

Bentivogli, E., Panicara, E. \& Tidu, A. (2008). “Il project finance nei servizi pubblici locali: poca finanza e poco progetto?", Questioni di Economia e Finanza, Banca d'Italia, 25 (in Italian).

Beria, P. (2008). “LE FERROVIE. Descrizione del settore ferroviario in Italia ed Europa”. Research Center of Transport Policy, Politecnico di Milano. Working paper (in Italian).

Bing, L., Akintoye, A., Edwards, P. J. \& Hardcastle C. (2005). "The allocation of risks in PPP/ PFI construction projects in the UK", International Journal of Project Management, Vol. 23 , pp. $25-35$.

Bovis, C. (2010). "Public Private Partnerships in the 21st century”, ERA Forum, 11, pp. $379-398$.

Carbonara, N., Costantino, N., Pellegrino, R. \& Sciancalepore, F. (2012). “Italian PPP applications: A Theoretical Framework”. In N. Carbonara \& A. Roumboutsos, (ed.), Public Private Partnerships in Transport: Trends \& Theory, ISBN 978-88-97781-04-2.

Cassa Depositi e Prestiti (CDP), (2012). "Porti e logistica. Il sistema portuale e logistico italiano nel contesto competitivo euromediterraneo: potenzialità e presupposti per il rilancio". Studio di settore. Maggio 2012 (in Italian).

Chinyio, E. \& Gameson, R. (2009). "Private Finance Initiative in Use”. In: Akintoye, A. \& Beck, M. (Eds.), Policy, Finance \& Management for Public-Private Partnerships, RICS Research, Wiley-Blackwell.

Clifton, C. \& Duffield, C. F. (2006). “Improved $\mathrm{PFI} / \mathrm{PPP}$ service outcomes through the integration of Alliances principles", International Journal of Project Management Vol. 24, pp. $573-586$.

Costantino, N., Chiara, N. \& Pellegrino, R. (2009). "PPP implementation throughout the world: a general selection/implementation scheme”, Proceedings of the CIB W055 and Wo65 Joint International Symposium "Construction Facing Worldwide Challenges”, Dubrovnik (Croatia) 27-30 September.

Costantino, N., Pellegrino, R. \& Sciancalepore, F. (2011). "Evaluation of different tolling systems for a transportation PPP project". In: Thai K.V., Towards New Horizons in Public Procurement, 301-316, PrAcademics Press, Boca Raton (USA).

Cresme, (2011). “10 Anni di Partenariato Pubblico Privato in Italia”. Report (in Italian).

de Pierris L. \& Pescarini G. (2001). “Italian PPP at a glance". Project Finance International Conference. 16 May, No. 217, pp. 73-77

Deakin, N. (2002). "Public-Private Partnerships: A UK case study". Public Management Review, Vol. 4, No. 2, pp. 133-147.

Dewulf, G., Duffield, C., Garvin, M., Widen, K., Peterson, O.H., Lamber, V., Scherrer, W. \& Olander, S. (2012). "The Emergence of Transport PPPs: Context and drivers”. In: N. Carbonara \& A. Roumboutsos, (ed.), Public Private Partnerships in Transport: Trends \& Theory, ISBN 978-88-97781-04-2.

Di Falco, G., Meneguzzo, M. \& Fiorani, G. (2009). "Financial crisis and future trends for PPP in local governments". MED2 Proceedings, Portoróz-Piran, Slovénie, 7-10 Octobre.

Etro, F. (2007). "Public Private Partnerships", Working Paper Series, No. 120, University of Milano Bicocca (in Italian).

ESCAP (2011). "Economic and Social Commission for Asia and the Pacific: A Guidebook on Public-Private Partnership in Infrastructure”, UNESCAP, Bangkok.

European Commission (2004). “Green Paper on public-private partnerships and Community law on public contracts and concessions", Brussels, COM(2004) 327 final.

Flinders, M. V. (2005). "The Politics of PublicPrivate Partnerships", British Journal of Politics and International Relations, Vol. 7, pp. $215-239$.

Garvin, M.J. \& Ford, D.N. (2012). "Real options in infrastructure projects: theory, practice and prospects", Engineering Project Organization Journal, Vol. 2, No.1-2, pp. 97-108.

Germani, A. (2005). “The PPP Experience in Italy (1999-2005)", The European PPP symposium, London May 24th.
Greve, C., \& Hodge, G. (2007). "PublicPrivate Partnerships: A Comparative Perspective on Victoria and Denmark". In: T. Christensen \& P. Lægreid (Eds.), Transcending New Public Management: The transformation of public sector reforms. UK: Ashgate.

Grimsey, D. \& Lewis, M.K. (2002). “Evaluating the risks of Public-Private Partnerships for infrastructure projects", International Journal of Project Management, Vol. 20, pp. 107-118.

Hammerschmid, G. \& Ysa, T. (2010). “Empirical PPP Experiences in Europe - National Variations of a Global Concept”. In: G. Hodge, C. Greve \& A.E. Boardman (eds.): International Handbook on Public-PrivatePartnerships, Cheltenham: Edward Elgar, 333-353.

Harris, C. (2003). “Private Participation in infrastructure in Developing countries. Trends, Impacts and Policy lessons”, World Bank Working Paper no. 5, World Bank, Washington DC.

Hemming, R. (2006). "Public-Private Partnerships, Government Guarantees, and Fiscal Risk". Washington D.C.: International Monetary Fund.

Hodge, G. \& Greve, C. (2005). The Challenge of Public-private Partnerships: Learning from International Experience, Edward Elgard Publishing (UK).

Iossa, E. \& Antellini Russo, F. (2008) “Potenzialità e criticità del Partenariato Pubblico Privato in Italia", Rivista di Politica Economica, Maggio-Giugno 2008, 125-158 (in Italian).

Jefferies, M., Gameson, R. \& Rowlinson, S. (2002). "Critical Success Factors of the BO0T Procurement System: Reflection from the Stadium Australia Case Study", Engineering, Construction and Architectural Management, Vol. 9, No. 4, pp. 352-361.

Johnston, J. \& Gudergan, S. P. (2007).

"Governance of public-private partnerships: lessons learnt from an Australian case?", International Review of Administrative Sciences, Vol. 73, No. 4, pp. 569-582.

Katz, G. \& Smith, S. (2003). “Build-OperateTransfer: The future of construction?", Journal of Construction Accounting and Taxation, Vol. 12, No. 1, 36-48. 
Klijn, E-.H. \& Teisman, G. (2003). „Institutional and Strategic Barriers to Public-Private Partnership: An Analysis of Dutch Cases", Public Money and Management, Vol. 23, No. 3, pp. $137-145$.

Koch, C. \& Buser, M. (2006). “Emerging metagovernance as an institutional framework for public private partnership networks in Denmark", International Journal of Project Management, Vol. 24, No. 7, pp. 548-556.

Koppenjan, J. (2005). “The Formation of PublicPrivate Partnerships. Lessons from Nine Transport Infrastructure Projects in the Netherlands", Public Administration, Vol. 83, No. 1, pp. 135-157.

LEGGE 28 gennaio 1994, n. 84 e successive modificazioni. Riordino della legislazione in materia portuale (in Italian).

Li, B. \& Akintoye, A. (2003). "An overview of public-private partnership”. In: Akintoye, A., Beck, M. \& Hardcastle, C. (Eds.). Public Private Partnerships: managing risks and opportunities, Blackwell Publishing.

Li, B., Akintoye, A., Edwards, P.J. \& Hardcastle, C. (2005a). "The Allocation of Risk in PPP/PFI Construction Projects in the UK”, International Journal of Project Management, Vol. 23, No. 1, pp. 25-35.

Li, B., Akintoye, A., Edwards, P.J. \& Hardcastle, C. (2005b). "Critical Success Factors for PPP/PFI Projects in the UK Construction Industry," Construction Management and Economic, Vol. 23, pp. 459-471.

Martiniello, L. (2008). “Italian PPP at a glance”, PPP Task Force.

McQuaid, R. \& Scherrer, W. (2010). “Changing reasons for public-private partnerships (PPPs)", Public Money and Management, Vol. 30, No. 1, pp. 27-34

Micelli, E. (2009). “Modelli ibridi di partnership pubblico-privato nei progetti urbani”, Scienze Regionali, Vol. 2 (in Italian).

MIT (2003). "Conto nazionale delle infrastrutture e dei trasporti", Ministero delle Infrastrutture e dei Trasporti, Istituto Poligrafico e Zecca dello Stato, Roma (Italy) (in Italian).

National Council for Public-Private Partnerships (NCPPP) (2003). “NCPPP White Paper”. The NCPPP, Washington DC.

OECD (2010). “Dedicated Public-Private Partnership Units: A Survey of Institutional and Governance Structures", OECD Publishing.

Postorino, M.N. (2009). Introduzione Alla Pianificazione del Sistema di Trasporto Aereo, Franco Angeli.

Pongsiri, N. (2002). "Regulation and PublicPrivate Partnerships", The International Journal of Public Sector Management, Vol. 15, No. 6, pp. 487-495.

Presilla, S. (2006). Il project financing in Italia, Le Fonti Editrice (in Italian).

Qiao, L., Wang, S.Q., Tiong, R.L.K. \& Chan, T.S. (2001). "Framework for Critical Success Factors of BOT Projects in China”, Journal of Project Finance, Vol. 7, No.1, pp. 53-61.

Reeves, E. (2003). "Public-Private Partnerships in Ireland: Policy and Practice", Public Money and Management, Vol. 23, No. 3, pp. 163-170.

Ricchi, M. (2009). “La nuova finanza di progetto nel rispetto dei contratti”, UTFP (in Italian).

Roumboutsos, A., Farrell, S., Liyanage, C. L. \& Macário, R. (2013). 2013 Discussion Papers. Part II Case Studies. ISBN 978-88-97781-61-5.

Scarnati, E. (2007). Analisi di bancabilità di progetti eolici, L'energia eolica: esperienze e prospettive, Rome, 15 November (in Italian).

Schaufelberger, J.E. \& Wipadapisutand, I. (2003). "Alternate Financing Strategies for Build-Operate-Transfer Projects", Journal of Construction Engineering and Management, Vol. 129, No. 2, pp. 205-213.

Smith, A.L. (2009). "PPP Financing in the USA". In: A. Akintoye \& M. Beck (Eds.), Policy, Finance \& Management for Public-Private Partnerships (pp. 198-212). Wiley-Blackwell.

Spackman, M. (2002). "Public-private partnerships: lessons from the British approach", Economic Systems, Vol. 26, No. 3, pp. 283-301.

Turina, N. \& Car-Pusic, D. (2006). “Overview of PPP models and the analysis of the opportunities for their application", Proceedings of the 7 th International Conference: Organization, Technology and Management in Construction, Zagreb, edited by Mladen Radujkovic.

Tvarnø, C. D. (2006). “Public-Private Partnerships from a Danish Perspective", Public Procurement Law Review, Vol.15, No. 3, pp. 98-108.

U.S. Department of Transportation (2007) Federal Highway Administration, "User Guidebook on implementing Public -
Private Partnerships for transportation infrastructure projects in the United States.

Unità Tecnica Finanza di Progetto (UTFP) (2009). 100 Questions and Answers.

Unità Tecnica Finanza di Progetto (UTFP) (2010). Partenariato Pubblico Privato in Italia. Stato dell'arte, futuro e proposte (in Italian).

Vigliano, F. \& Bicchieri, N. (2007). "Italy in GLG”, The International Comparative Legal Guide to: PFI/PPP Projects 2007.

Ye, S. (2009). "Patterns of Financing PPP Projects". In: Akintoye, A. and Beck, M. (Eds.), Policy, Finance \& Management for Public-Private Partnerships, RICS Research, Wiley-Blac.

Ysa, T. (2007). “Governance Forms in Urban Public-Private Partnerships”, International Public Management Journal, Vol. 10, No. 1, pp. 35-57.

Zhang, X.Q. (2005a). “Financial Viability Analysis and Capital Structure Optimization in Privatized Public Infrastructure Projects", Journal of Construction Engineering and Management, Vol. 131, No. 6, pp. 656-668

Zhang, X.Q. (2005b). “Criteria for Selecting the Private-Sector Partner in Public-Private Partnerships", Journal of Construction Engineering and Management, Vol. 131, No. 6, pp. 631-644.

Zhang, X.Q. (2005C). “Critical Success Factors for Public-Private Partnerships in Infrastructure Development", Journal of Construction Engineering and Management, Vol. 131, No.1, pp. 3-14. 